DOI.

https://doi.org/10.22219/fths.v3i1

Received: Desember 2019

Accepted: Januari 2019

Available online: Februari 2020

\title{
Pemanfaatan Tepung Biji Nangka (Artocarpus heterophyllus) dan Tepung Singkong (Manihot esculenta) Dengan Penambahan Pigmen Klorofil Pada Sayuran Sebagai Sumber Antioksidan Beras Analog
}

\author{
Silvia Khilmi ${ }^{1}$, Damat $^{1^{*}}$, Elfi Anis Saati ${ }^{1}$ \\ ${ }^{1}$ Program Studi Teknologi Pangan, Fakultas Pertanian Peternakan, Universitas \\ MuhammadiyahMalang, Malang, Indonesia \\ *Corresponding author email: damat@umm.ac.id
}

\begin{abstract}
Jackfruit seeds have high carbohydrate and protein, which is around 56.21\% and $12.19 \%$. Substitution with cassava starch which has amylose and amylopectin can help analog rice characteristics. The addition of natural dyes such as chlorophyll is also needed in the diversification of analog rice food as a source of antioxidants. The purpose of this study was to find out the diversification of jackfruit seed processing through the use of jackfruit seed flour and cassava flour substitution into analog rice, determine the effect of adding extracts to different vegetables on the physicochemical and organoleptic properties of analog rice, knowing the presence of chlorophyll and antioxidant content in analog rice substitution jackfruit seed flour and cassava flour. This study uses a Nested desaign / nested design. Nest / parent namely the proportion of flour with 3 levels (10\% jackfruit seed flour and 90\% cassava flour, 20\% jackfruit seed flour and $80 \%$ cassava flour, 30\% jackfruit seed flour and 70\% cassava flour) and the nest is pigment with 4 levels (without pigments, green spinach pigments, suji leaf pigments, moringa leaf pigments). The results showed a very significant effect on water content, ash content, fat, protein, carbohydrates, antioxidants, chlorophyll, absorption, brightness, color ( $\left.a^{-}\right)$and color $(b+)$, rendemen and organoleptics such as taste, texture, shape and liking. Organoleptic texture has no real effect. The best treatment for T3W2 treatment is the proportion of 30\% jackfruit seed flour and 70\% tapioca flour with the addition of pigment from green spinach.
\end{abstract}

Keywords : analog rice, antioxidants, jackfruit seeds, chlorophyll

\section{PENDAHULUAN}

Kebiasaan masyarakat makan nasi tiga kali sehari membuat masyarakat sulit mengalihkan konsumsinya ke sumber pangan non beras. Untuk membuat bahan pangan non beras mampu menarik hati masyarakat, sumber bahan pangan lokal non beras harus diolah sedemikian rupa sehingga berkarakteristik seperti beras, baik dalam segi sifat-sifat fisik butiran, penanakan dan tekstur. Produk mirip beras yang dibuat dari bahan yang bukan beras tersebut lebih dikenal sebagai beras analog (machmur et al., 2011). Beras analog dapat dibuat dari berbagai macam tepung yang mengandung 
karbohidrat, seperti tepung biji nangka. Substitusi pati biji nangka ke dalam beras analog dengan bahan pati singkong. Ada dua proses yang digunakan untuk membuat beras analog, yaitu proses granulasi dan proses ekstrusi.

Pemanfaatan biji buah nangka oleh masyarakat sangat terbatas dan belum dimanfaatkan secara optimal sebagai komoditi yang memiliki nilai lebih. Biji nangka mengandung karbohidrat yang cukup tinggi dan potensial untuk diolah menjadi produk pangan. Pemanfaatan tepung biji nangka sebagai bahan baku atau pensubstitusi tepung terigu merupakan upaya yang dapat mengurangi ketergantungan masyarakat terhadap beras. Berdasarkan penelitian terdahulu diketahui bahwa beras analog yang terbuat dari pati singkong menghasilkan bentuk beras analog yang tidak sempurna pada saat penyajian,sehingga perlu ditambahkan pati dari bahan pangan lain untuk memperbaiki bentuk beras analog. Pati biji nangka memiliki kadar amilosa yang lebih tinggi dibandingkan tepung tapioka. Kadar amilosa pada pati bijinangka $28,1 \%$, sedangkan kadar amilosa pada tepung tapioka hanya $17,41 \%$ (putri, 2009), sehingga dapat mempengaruhi karakteristik beras analog. Penambahan pewarna alami juga diperlukan dalam diversifikasi pangan terhadap beras analog untuk menambah estetika beras dan seperti warna hijau yang biasanya disebut dengan klorofil. Daun dan sayuran yang berpigmen klorofil diketahui mengandung antioksidan yang dapat menangkal radikal bebas dalam tubuh sehingga dapat menjaga kesehatan tubuh ketika mengkonsumsinya. Antioksidan merupakan senyawa yang dapat menghambat reaksi oksidasi, dengan cara mengikat radikal bebas dan molekul yang sangat reaktif. Salah satu bentuk senyawa oksigen reaktif adalah radikal bebas, senyawa ini terbentuk di dalam tubuh dan dipicu oleh bermacam-macam faktor (winarsi, 2007).

Pigmen klorofil dapat didapatkan dari daun seperti daun suji, daun kelor dan sawi. Daun suji merupakan salah satu sumber pigmen klorofil yang paling banyak digunakan sebagai pewarna hijau pada makanan tradisional. Untuk mendapatkan pewarna dari daun suji dilakukan dengan menumbuk daun dan diekstrak dengan air. Daun suji secara tradisional digunakan sebagai pewarna makanan namun seiring perkembangan jaman, daun suji dapat digunakan sebagai pewarna teksil batik. Serta juga digunakan sebagai obat tradisional sebagai obat gonorhoe, obat beri-beri dan lain-lain. (diana sofiatun, 2013). Selain daun suji, daun kelor memiliki warna hijau. Daun kelor juga memiliki kelebihan yakni mengandung antioksidan tinggi dan antimikrobia (das et al., 2012). Kandungan besi pada bayam relatif lebih tinggi dari pada sayuran daun lain (besi merupakan penyusun sitokrom, protein yang terlibat dalam fotosintesis) sehingga berguna bagi penderita anemia. Daun bayam mempunyai kandungan klorofil yang tinggi. Adapun tujuan yang ingin dicapai 
dari pelaksanaan penelitian antara lain sebagai berikut mengetahui karakteristik fisiko kimia beras analog melalui pemanfaatan tepung biji nangka dan tepung singkong .mengetahui karakteristik fisiko kimia beras analog akibat penambahan ekstrak pigmen daun suji, bayam dan daun kelor.mengetahui adanya interaksi pigmen klorofil pada beras analog sebagai zat gizi antioksidan.

\section{METODE PENELITIAN}

\section{Bahan}

Bahan yang digunakan antara lain biji nangka, tapioka, sari daun suji, sari bayam hijau dan sari daun kelor.

Alat

Peralatan yang digunakan dalam penelitian adalah timbangan analitik merk pioneer ohaus pa413, cabinet dryer, spektrofotometer merk shimadzu uv1800, desikatormerk glaswerk werthein 6132, waterbath shaker, juicer, hotplate magnetic stirrer merk barnstead thermolyne cimarec 2, colour reader cr 10 merk conica minota.

\section{Ekstrak Pigmen Klorofil}

Daun suji, bayam hijau dan daun kelor dilakukan proses sortasi untuk memilih bahan yang baik dan tidak layu. Bahan kemudian dibersihkan untuk menghilangkan kotoran lainnya. Bahan yang sudah dibersihkan dari kotoran kemudian ditiriskan. Bahan dimasukkan ke dalam juicer untuk mendapatkan sari. Sari yang didapatkan kemudian diukur untuk dilakukan proses lanjutan yaitu proses pembuatan beras analog. Sari yang telah jadi diukur sesuai dengan komposisi yang telah ditentukan kemudian ditambahkan kedalam adonan tepung untuk pembuatan beras analog.

\section{Pembutan Tepung Biji Nangka}

Proses pembuatan tepung meliputi proses awal yaitu sortasi dengan air mengalir untuk mendapatkan biji nangka yang bagus serta menghilangkan kotoran yang menempel. Biji nangka yang bersih kemudian dilakukan proses selanjutnya yaitu pengukusan. Setelah tahap pengukusan biji nangka dikupas untuk menghilangkan kulitnya. Biji nangka yang telah dikupas kemudian diperkecil ukurannya lalu dikeringkan selama 24jam. Biji nangka kering dihaluskan menggunakan blender untuk menghasilkan tepung biji nangka.

Pembuatan Beras Analog Proporsi Tepung Biji Nangka dan Tepung Tapioka dengan Penambahan Sumber Pigmen yang Berbeda

Bahan utama dalam pembuatan beras analog adalah tepung biji nangka dan tepung tapioca. GMS digunakan untuk memperbaiki karakter fisik dari beras analog. Proses pembuatan beras analog yaitu dilakukan penimbangan bahan baku tepung sesuai dengan proporsi. Tepung biji nangka, tepung tapioca, 
GMS dan pigmen dengan jenis yang berbeda kemudian dicampur sesuai dengan komposisi Yang telah ditentukan. Bahan yang telah tercampur dibungkus dengan kain saring serta dilakukan pengukusan selama 30 menit dengan suhu 80oC. Kemudian dilanjutkan proses ekstruksi dalam suhu 100oC dengan menggunakan mesin ekstruder untuk mendapatkan butiran beras. Setelah mendapatkan butiran beras analog kemudian dilanjutkan proses pengeringan menggunakan cabinet dyer dengan suhu 50oC selama 24jam. Beras analog yang telah kering dilakukan pengayakan menggunakan mesin sosoh untuk memisahkan butiran beras yang bagus. Beras analog yang telah jadi, kemudian ditimbang untuk dihitung rendemen dari bahan tersebut.

\section{Parameter Penelitian}

Analisa pada bahan baku ekstrak suji, bayam hijau dan kelor adalah analisa klorofil dan antioksidan. Analisa produk beras analog meliputi kadar air, kadar abu, protein, lemak, karbohidrat, aktivitas antioksidan, klorofil, intensitas warna, daya serap air, organoleptik (rasa, tekstur, bentuk dan kesukaan). Analisa nasi analog meliputi analisa protein dan aktivitas antioksidan.

\section{Rancangan Percobaan dan Analisa Data}

Penelitian dilakukan dengan menggunakan rancangan nested design (desain tersarang). Sarang / induk yaitu pigmen (W) dengan 4 level (tanpa pigmen, pigmen bayam hijau, pigmen daun suji, pigmen daun kelor) dan tersarang yaitu proporsi tepung (T) dengan 3 level (tepung biji nangka 10\%, tepung biji nangka 20\%, tepung biji nangka 30\%) yang dianalisa sebanyak 3 kali ulangan.

Data pengamatan terhadap beras analog fisikokimia dan uji organoleptik dianalisa menggunakan analisa Ragam atau Analysis of Variance (ANOVA) untuk mengetahui pengaruh dari kedua perlakuan.Hasil yang menunjukkan adanya pengaruh nyata akan dianalisa menggunakan uji BNJ dengan taraf signifikan $\alpha=5 \%$.

\section{HASIL DAN PEMBAHASAN}

\section{pH Bahan Baku}

Nilai aktivitas antioksidan dari ekstrak suji memiliki kadar tertinggi yaitu 0,362, jika dibandingkan dengan nilai aktivitas antioksidan bayam dan kelor yakni sebesar 0,244 dan 0,196. Menurut tina (2015) bahwa tinggi rendahnya nilai aktivitas antioksidan yang didapatkan dipengaruhi oleh sumper pigmen yang digunakan. Tubuh manusia dapat menetralisir radikal bebas bila jumlahnya tidak berlebihan, dengan mekanisme pertahanan antioksidan endogen. Nilai klorofil dari ekstrak bayam memiliki kadar klorofil 
tertinggi yaitu 0,102. Apabila dibandingkan dengan ekstrak suji dan kelor yakni sebesar 0,057 dan 0.091. Klorofil memiliki peran dalam kesehatan karena beberapa senyawa turunannya mengandung antioksidan, antikarsiogenik dan antiinflasi. Klorofil memiliki enzim suproksida dismutase yang berfungsi sebagai antioksidan dan menetralkan aktivitas radikal bebas dalam tubuh. Menurut tina (2015) menyatakan bahwa klorofil berpotensi sebagai antioksidan serta dapat mencegah oksidasi berlebihan dalam tubuh

Tabel 1. Komposisi pati bonggol pisang dalam 100 gram

\begin{tabular}{llll} 
Parameter & Suji & Bayam & Kelor \\
\hline Aktivitas antioksidan (\%) & 0,362 & 0,244 & 0,196 \\
Total klorofil (mg/l) & 0,057 & 0,102 & 0,091 \\
\hline
\end{tabular}

\section{Karakteristik Beras Analog \\ Kadar Air}

Berdasarkan pada tabel 2, diketahui bahwa kadar air pada perlakuan tanpa pigmen sebesar 5,59370 , perlakuan dengan pigmen suji 6,30131\%, perlakuan dengan pigmen bayam 7,49106 \% dan perlakuan dengan pigmen daun kelor $6,85143 \%$. Beras analog dengan tanpa penambahan pigmen memiliki kadar air terendah dibandingkan perlakuan penambahan pigmen yang lainnya. Tinggi rendahnya kadar air pada beras analog dipengaruhi oleh pigmen yang ditambah dalam beras analog memiliki kadar air yang berbeda sehingga berpengaruh terhadap beras analog yang dihasilkan. Pigmen yang ditambahkan dapat mempengaruhi kadar air dalam beras analog. Menurut suhardianto dan purnama (2011) bahwa dalam $100 \mathrm{~g}$ bayam hijau memiliki kandungan air sekitar $85-90 \%$ dan daun kelor memiliki kandungan air sekitar $75 \%$. Daun suji memiliki kandungan air terendah dari bayam dan kelor, yaitu sebesar $73,5 \%$ (prangdimurti, 2006).

\section{Kadar Abu}

Berdasarkan tabel 3 dapat diketahui proporsi tepung biji nangka dan tepung singkong 20\%:80\% pada bayam hijau memiliki kadar abu tertinggi yaitu $0,448 \%$. Hal ini dikarenakan tepung biji nangka mengandung mineral seperti fosfor $200 \mathrm{mg}$, kalsium $33 \mathrm{mg}$, dan besi 1,0 mg. Mineral cukup stabil selama pemanasan sehingga cenderung tidak berubah selama proses pemanggangan. Penambahan bahan seperti tepung tapioka sangat berpengaruh terhadap peningkatan kadar abu dari beras analog karena mineral yang terkandung pada tepung tapioca cukup besar. Unsur mineral dikenal sebagai zat organic atau kadar abu. Dalam proses pembakaran, bahan-bahan organic terbakar tetapi zat 
anorganik tidak ikut terbakar. Menurut winarno (2004) bahwa abu merupakan residu anorganik dari hasil pembakaran atau hasil oksidasi komponen organik bahan pangan.

Tabel 2. Kadar air beras analog interaksi antar jenis pigmen dan proporsi tepung biji nangka dan tepung singkong

\begin{tabular}{lclllll}
\hline $\begin{array}{l}\text { Jenis } \\
\text { pigmen }\end{array}$ & $\begin{array}{l}\text { Proporsi tepung } \\
\text { biji nangka dan } \\
\text { tepung singkong }\end{array}$ & $\begin{array}{l}\text { Kadar air } \\
(\%)\end{array}$ & $\begin{array}{l}\text { Abu } \\
(\%)\end{array}$ & $\begin{array}{l}\text { Lemak } \\
(\%)\end{array}$ & $\begin{array}{l}\text { Protein } \\
(\%)\end{array}$ & $\begin{array}{l}\text { Karbohidrat } \\
(\%)\end{array}$ \\
\hline Tanpa & $10 \%: 90 \%$ & $5,038 \mathrm{e}$ & $0,390 \mathrm{ab}$ & $3,799 \mathrm{ab}$ & $4,174 \mathrm{f}$ & $88,967 \mathrm{a}$ \\
pigmen & $20 \%: 80 \%$ & $5,910 \mathrm{cde}$ & $0,268 \mathrm{ab}$ & $6,114 \mathrm{a}$ & $4,450 \mathrm{ef}$ & $86,184 \mathrm{abcd}$ \\
& $30 \%: 70 \%$ & $5,831 \mathrm{de}$ & $0,157 \mathrm{~b}$ & $3,119 \mathrm{ab}$ & $4,799 \mathrm{def}$ & $88,949 \mathrm{a}$ \\
Daun & $10 \%: 90 \%$ & $6,172 \mathrm{bcde}$ & $0,199 \mathrm{~b}$ & $2,606 \mathrm{~b}$ & $8,608 \mathrm{a}$ & $85,506 \mathrm{bcd}$ \\
suji & $20 \%: 80 \%$ & $6,312 \mathrm{abcde}$ & $0,275 \mathrm{ab}$ & $2,359 \mathrm{~b}$ & $8,112 \mathrm{ab}$ & $86,077 \mathrm{abcd}$ \\
& $30 \%: 70 \%$ & $6,418 \mathrm{abcde}$ & $0,288 \mathrm{ab}$ & $2,575 \mathrm{~b}$ & $7,923 \mathrm{ab}$ & $86,029 \mathrm{abcd}$ \\
Bayam & $10 \%: 90 \%$ & $7,378 \mathrm{abc}$ & $0,218 \mathrm{ab}$ & $5,030 \mathrm{ab}$ & $7,205 \mathrm{abc}$ & $83,971 \mathrm{~d}$ \\
hijau & $20 \%: 80 \%$ & $7,435 \mathrm{ab}$ & $0,448 \mathrm{a}$ & $3,046 \mathrm{ab}$ & $6,633 \mathrm{bc}$ & $86,282 \mathrm{abcd}$ \\
& $30 \%: 70 \%$ & $7,658 \mathrm{a}$ & $0,238 \mathrm{ab}$ & $4,487 \mathrm{ab}$ & $7,066 \mathrm{bc}$ & $84,522 \mathrm{~cd}$ \\
Daun & $10 \%: 90 \%$ & $6,690 \mathrm{abcd}$ & $0,325 \mathrm{ab}$ & $2,813 \mathrm{~b}$ & $5,945 \mathrm{cde}$ & $87,638 \mathrm{ab}$ \\
kelor & $20 \%: 80 \%$ & $7,029 \mathrm{abcd}$ & $0,167 \mathrm{~b}$ & $4,121 \mathrm{ab}$ & $6,035 \mathrm{~cd}$ & $86,210 \mathrm{abcd}$ \\
& $30 \%: 70 \%$ & $6,835 \mathrm{abcd}$ & $0,246 \mathrm{ab}$ & $2,027 \mathrm{~b}$ & $6,990 \mathrm{bc}$ & $87,366 \mathrm{abc}$ \\
\hline
\end{tabular}

Nilai rata-rata yang diikuti oleh huruf yang sama, menunjukkan tidak berpengaruh nyata menurut uji $\mathrm{BNJ} \alpha=5 \%$

\section{Kadar Lemak}

Berdasarkan Tabel 2 dapat diketahui bahwa proporsi tepung 20\%:80\% tanpa pigmen memiliki kadar lemak tertinggi yaitu 6,114\%. Dan proporsi tepung 20\%:80\% dengan penambahan pigmen daun suji memiliki kadar lemak terendah yaitu 2,359\%. Hal ini diduga karena proporsi tepung yang digunakan berpengaruh terhadap lemak beras analog. Menurut ocloo (2010) bahwa tepung biji nangka mengandung komponen gizi yaitu lemak sebesar 1,12\%. Sedangkan tepung tapioka mengandung kadar lemak yaitu $0,2 \%$ (ridal, 2003).

\section{Kadar Protein}

Berdasarkan data pada Tabel 2, diketahui bahwa kadar protein beras analog tertinggi pada perlakuan pigmen suji dengan proporsi tepung 10\%:90\% yaitu $8,608 \%$ dan terendah pada perlakuan tanpa pigmen dengan proporsi tepung 10\%:90\%. Dalam sni kandungan protein tidak termasuk ke dalam 
persyaratan mutu beras analog yang ditetapkan karena pada tergolong rendah. Namun pada beras analog ini terdapat protein $12,9 \%$ pada tepung biji nangka.

\section{Kadar Karbohidrat}

Berdasarkan Tabel 2, dapat diketahui bahwa karbohidrat tertinggi adalah pada proporsi tepung 10\%:90\% yaitu 88,9675. Karbohidrat terendah adalah pada proporsi tepung 30\%:70\% yaitu 84,522 \%. Menurut yuliyanti (2012) bahwa dalam analisa proksimat nasi analog, kadar karbohidrat dapat mencapai 90\% yang berasal dari komposisi dominan dari bahan baku yang digunakan. Bahan baku tersebut biasanya merupakan sumber karbohidrat lokal. Menurut badan ketahanan pangan dan penyuluhan provinsi diy (2012) bahwa kandungan nutrisi karbohidrat pada tepung tapioca adalah sebesar $86,9 \%$, sementara itu menurut melo (2013) bahwa karbohidrat yang terkandung dalam biji nangka adalah sebesar $36,7 \%$. Penelitian ini menunjukkan bahwa kadar karbohidrat biji nangka cukup tinggi, sesuai dengan hasil penelitian yang dikemukakan oleh fairus (2010) bahwa kandungan karbohidrat biji nangka 36,7\% dari 100 gram bagian yang dapat dimakan. Dengan demikian, biji nangka dapat bermanfaat akan menambah nilai ekonomis yang lebih tinggi dengan cara diversifikasi pangan atau penaganekaragaman pangan sebagai beras analog.

\section{Kadar Klorofil dan Aktivitas Antioksidan}

Menurut uji BNJ didapatkan hasil bahwa kadar klorofil terdapat beras analog ini yaitu kisaran antara 1,438\% sampai 6,153\%. Kadar klorofil tertinggi terdapat perlakuan pigmen suji dengan proporsi tepung 30\%:70\% yaitu 6,153\%, dan kadar klorofil terendah yaitu tanpa pigmen dengan proporsi tepung 10\%:90\%. Semakin tinggi kadar klorofil dalam beras akan semakin baik karena memperbaiki kenampakan dan daya tarik produk beras analog. Beras analog berpengaruh Terhadap klorofil yang dipengaruhi oleh cahaya, panas dan oksigen. Hal ini juga disampaikan nurdin (2009) yang menyatakan bahwa karakteristik penting dari klorofil adalah kelabilannya yang ekstrim yaitu sensitive terhadap cahaya, panas dan oksigen.

Berdasarkan data pada Tabel 3, dapat diketahui bahwa proporsi tepung dan pigmen sangat berpengaruh nyata terhadap nilai aktivitas beras analog. Nilai aktivitas antioksidan tertinggi adalah pada pigmen bayam proporsi tepung 30\%:70\% yaitu 55,106\%. Nilai teredah adalah tanpa pigmen dengan proporsi tepung $10 \%: 90 \%$ yaitu $22,246 \%$. Hal ini disebabkan tepung biji nangka memiliki fitonutriet seperti lignin, isoflavon serta saponin yang merupakan senyawa antioksidan. Antioksidan adalah komponen yang dapat mencegah atau menghambat oksidasi lemak, asam nukleat, atau molekul lainnya dengan 
mencegah inisiasi atau perkembangan dari reaksi berantai. Senyawa radikal yang berasal dari tubuh (eksogen) maupun dari dalam tubuh (endogen) yang terbentuk dari hasil metabolisme zat gizi secara normal. Proses fisiologis timbulnya senyawa radikal tubuh yang pro oksidan akan diimbangi oleh mekanisme pertahanan endogen dengan menggunakan senyawa yang memiliki kemampuan sebagai anti radikal bebas (rahmawati, 2011).

Tabel 3. Klorofil beras analog interaksi antar jenis pigmen dan proporsi tepung biji nangka dan tepung singkong

\begin{tabular}{lcll}
\hline Jenis pigmen & $\begin{array}{l}\text { Proporsi tepung biji } \\
\text { nangka dan tepung } \\
\text { singkong }\end{array}$ & Klorofil (\%) & $\begin{array}{l}\text { Aktivitas } \\
\text { antioksidan (\%) }\end{array}$ \\
\hline Tanpa pigmen & $10 \%: 90 \%$ & $1,438 \mathrm{~g}$ & \\
& $20 \%: 80 \%$ & $1,748 \mathrm{fg}$ & $22,246 \mathrm{e}$ \\
Daun suji & $30 \%: 70 \%$ & $2,353 \mathrm{efg}$ & $23,501 \mathrm{de}$ \\
& $10 \%: 90 \%$ & $5,211 \mathrm{abc}$ & $24,675 \mathrm{de}$ \\
Bayam hijau & $20 \%: 80 \%$ & $5,748 \mathrm{ab}$ & $30,004 \mathrm{de}$ \\
& $30 \%: 70 \%$ & $6,153 \mathrm{a}$ & $31,875 \mathrm{~cd}$ \\
Daun kelor & $10 \%: 90 \%$ & $3,453 \mathrm{cdef}$ & $32,909 \mathrm{~cd}$ \\
& $20 \%: 80 \%$ & $4,046 \mathrm{bcde}$ & $40,980 \mathrm{bc}$ \\
& $30 \%: 70 \%$ & $5,111 \mathrm{abcd}$ & $46,351 \mathrm{ab}$ \\
& $10 \%: 90 \%$ & $2,822 \mathrm{efg}$ & $55,106 \mathrm{a}$ \\
& $20 \%: 80 \%$ & $3,020 \mathrm{efg}$ & $30,989 \mathrm{de}$ \\
\hline
\end{tabular}

Nilai rata-rata yang diikuti oleh huruf yang sama, menunjukkan tidak berpengaruh nyata menurut uji BNJ $\alpha=5 \%$

\section{Organoleptik}

Analisa hedonic menunjukkan rasa yang paling disukai adalah T3W1 dan yang kurang disukai adalah T3W3. Hal ini dikarenakan rasa yang terdapat pada nasi analog bayam cenderung lebih enak dan tidak pahit dibandingkan dengan nasi analog dengan penambahan pigmen suji karena penambahan pigmennya lebih pekat, sehingga sangat berpengaruh terhadap rasa pada nasi analog. Pada beras analog tekstur dipengaruhi oleh bahan baku yang digunakan. Proporsi tepung yang digunakan juga sangat berpengaruh terhadap tekstur nasi analog. Tepung tapioca yang digunakan mengandung amilosa dan amilopektin yang cukup tinggi sehingga dapat membantu pembentukan gel saat proses berlangsung. Menurut suarni (2005) menyatakan bahwa amilopektin merupakan kandungan yang mempengaruhi tekstur beras analog. Semakin 
tinggi kandungan amilopektin maka semakin lunak, puler dan enak rasanya. Analisa hedonik tekstur dapat dilihat pada Tabel 4 yang menunjukkan tekstur tidak berpengaruh nyata. Hal ini dikarenakan subjektifitas panelis cenderung tidak berbeda. Sehingga tekstur berdarkan panelis menunjukkan hasil yang tidak terlalu signifikan.selain itu tekstur nasi analog dipengaruhi oleh proses berlangsungnya pembuatan beras analog dan kadar air yang terserap dalam nasi analog.

Tabel 4. Rasa beras analog dengan pigmen hijau dari tepung biji nangka dan tepung singkong

\begin{tabular}{lcllll}
\hline $\begin{array}{l}\text { Jenis } \\
\text { pigmen }\end{array}$ & $\begin{array}{l}\text { Rasio tepung biji } \\
\text { nangka dan } \\
\text { tepung singkong }\end{array}$ & Rasa & Kesukaan & Bentuk & Tekstur \\
\hline Tanpa & $10 \%: 90 \%$ & $5,130 \mathrm{abc}$ & $5,130 \mathrm{abcd}$ & $4,739 \mathrm{~cd}$ & 4,650 \\
pigmen & $20 \%: 80 \%$ & $4,826 \mathrm{bc}$ & $4,956 \mathrm{abcd}$ & $5,217 \mathrm{abc}$ & 4,600 \\
& $30 \%: 70 \%$ & $5,391 \mathrm{abc}$ & $5,562 \mathrm{a}$ & $4,869 \mathrm{bcd}$ & 4,398 \\
Daun suji & $10 \%: 90 \%$ & $5,521 \mathrm{abc}$ & $5,521 \mathrm{ab}$ & $5,608 \mathrm{ab}$ & 4,661 \\
& $20 \%: 80 \%$ & $4,869 \mathrm{bc}$ & $5,478 \mathrm{abc}$ & $5,347 \mathrm{abc}$ & 4,578 \\
& $30 \%: 70 \%$ & $5,956 \mathrm{a}$ & $5,826 \mathrm{a}$ & $5,956 \mathrm{a}$ & 4,523 \\
Bayam & $10 \%: 90 \%$ & $5,260 \mathrm{abc}$ & $5,217 \mathrm{abcd}$ & $4,130 \mathrm{~d}$ & 4,700 \\
hijau & $20 \%: 80 \%$ & $5,173 \mathrm{abc}$ & $5,260 \mathrm{abc}$ & $5,695 \mathrm{a}$ & 4,681 \\
& $30 \%: 70 \%$ & $5,217 \mathrm{abc}$ & $5,391 \mathrm{abc}$ & $5,565 \mathrm{ab}$ & 4,574 \\
Daun & $10 \%: 90 \%$ & $5,652 \mathrm{ab}$ & $4,521 \mathrm{bcd}$ & $5,739 \mathrm{a}$ & 4,712 \\
kelor & $20 \%: 80 \%$ & $5,173 \mathrm{abc}$ & $4,217 \mathrm{~d}$ & $5,782 \mathrm{a}$ & 4,705 \\
& $30 \%: 70 \%$ & $4,565 \mathrm{c}$ & $4,478 \mathrm{~cd}$ & $5,869 \mathrm{a}$ & 4,520 \\
\hline
\end{tabular}

Nilai rata-rata yang diikuti oleh huruf yang sama, menunjukkan tidak berpengaruh nyata menurut uji BNJ $\alpha=5 \%$

Penilaian kesukaan panelis memiliki penilaian yang subjektif karena kesukaan dapat dilihat dari segi bentuk, rasa, tekstur serta kenampakan suatu bahan. Kesukaan panelis tertinggi pada nasi analog ini adalah pada T3W2 karena memiliki warna dan bentuk yang disukai oleh panelis. Selain itu rasa pada nasi analog T3W1 yaitu 5,826\% juga disukai oleh panelis dibandingkan dengan nilai terendah yaitu T2W3 yaitu 4,217\%. Hal ini dikarenakan komposisi tepung yang digunakan sesuai karena tidak terlalu lengket. Selain itu pigmen suji yang ditambahkan memiliki warna yang bagus dan tidak menimbulkan rasa pahit sehingga banyak disukai oleh panelis. Menurut winarno (2005) panelis bertugas menilai sifat atau mutu komoditi berdasarkan kesan subjektif dan pengujian organoleptip mengandalkan indra manusia bersifat subjektif karena setiap orang memiliki selera yang berbeda. 
Bentuk pada nasi analog juga berpengaruh terhadap kapasitas beras menyerap kandungan air, seperti pada proporsi T3W3 yaitu menggunakan tepung biji nangka 30\% akan menghasilkan bentuk yang lebih bagus dan bulir. Hal ini disebabkan karena tepung biji nangka memiliki amilosa dan amilopektin yang lebih banyak. Berdasarkan penelitian terdahulu juga dinyatakan bahwa beras analog berbahan baku tepung singkong memiliki karakteristif fisik yang belum sempurna, sehingga terdapat penambahan tepung biji nangka dengan proporsi 30\% untuk menghasilkan bentuk yang cukup sempurna seperti bulir.

\section{KESIMPULAN}

Penganekaragaman biji nangka dan singkong menjadi beras analog berpengaruh terhadap sifat fisiko kimia meliputi kadar abu, kadar air, lemak, protein, karbohidrat, antioksidan, klorofil dan organoleptic yaitu rasa, kesukaan, tekstur dan bentuk. Penambahan pigmen hijau seperti daun suji, daun bayam dan daun kelor berpengaruh terhadap sifat fisiko kimia seperti kadar air, kadar abu, protein, lemak, karbohidrat, antioksidan, klorofil dan organoleptik. Semakin tinggi nilai klorofil maka semakin tinggi pula nilai aktivitas antioksidan. Klorofil dipengaruhi oleh jenis pigmen yang ditambahkan. Klorofil juga berpengaruh terhadap kenampakan produk dan antioksidan. Antioksidan yang memiliki nilai rendah disebabkan oleh rusaknya antioksidan karena tidak tahan pada suhu panas.

\section{REFERENSI}

Agustina, W. dan Yusuf, A. 2010. Karakteristik Yoghurt Susu Nabati Kacang Hijau (Phaseolus radiatus L.). Balai Besar Pengembangan Teknologi Tepat Guna. LIPI. Bandung. Jurnal.

Aini, N. Prihananto, V., Wijonarko, G., Arimah, A., Syaifuddin, M. 2017. Pengaruh Konsentrasi Kultur dan Prebiotik Ubi Jalar terhadap Sifat Sari Jagung Manis Probiotik. Jurnal Agritech, Vol. 37, No. 2. Program Studi Ilmu dan teknologi Pangan. Universitas Jendral Soedirman.

Andrianto, T. T dan N. Indarto. 2004. Budidaya dan Analisis Usaha Tani; Kedelai, Kacang Hijau, Kacang Panjang. Yogyakarta: Penerbit Absolut. Cetakan Pertama. Hal. 9-92. Dalam Skripsi M. Ikmal Tawakkal. P. 2009. Respon Pertumbuhan dan Hasil Produksi Beberapa Varietas Kedelai (Glycine Max L) Terhadap Pemberian Pupuk Kandang Kotoran Sapi. Universitas Sumatera Utara. Medan.

AOAC, 2000. Official Methods of Analysis of The Association of Analytical Chemists. Washington D.C.

Astawan, M. 2005. Info Teknologi Pangan Department of Food Science and Technology, Faculty of Agricultural Technology and Enginering, Bogor Agricultural University.

Badan Standarisasi Nasional Indonesia. 2009 Syarat Mutu Yoghurt. SNI No. 012981-2009. Fardiaz, S. 2003. Analisis Mikrobiologi Pangan. Jakarta: Raja 
Grafindo Persada.

FDA. 2009. Milk and cream products and yogurt products. Food and Drug Administration Federal Register 74:2448.

Gallardo-Escamilla, F.J., Kelly, A.L dan Delahunty, C.M. 2005. Influence of starter culture on flavor and headspace volatile profiles of fermented whey and whey produced from fermented milk. Journal of dairy Science 88: 3745-3753.

Gilliland, S.E. 2005. Bacterial Starter Culture for Foods. CRC Press. Boca Raton.

Gustaw, W., Kordowska-Wiater, M. dan Kozioł. J. 2011. The influence of selected prebiotics on the growth of lactic acid bacteria for bio-yoghurt production. Acta Science. Polymer Technology 10(4): 455-466.

Haydersah, J., Chevallier, I., Rochette Astawan, Made. 2008. Sehat dengan Hidangan ewani.Jakarta:Penebar Swadaya

Kaur, C. and Kapoor, H.C. 2002. Anti-oxidant activity and total phenolic content of some Asian vegetables. International Jour. of Food Science and Technology 37, 153-161.

Koswara, S. 2009.Teknologi Pengolahan Singkong.Fakultas TeknologiPertanian, Institut Pertanian Bogor,Bogor.26 hlm. Lingga, Lani. 2012. Cerdas Memilih Sayuran. Jakarta: PT AgroMedia Pustaka.

Melo, N.V., Vargas, T. Quirino and C. M. C.Calvo. (2013). Moringa oleifera L. An underutilized tree with macronutrients for human health.

Nurdin, Clara, dan Januwati. (2009).Kandungan Klorofil Berbagai Jenis Daun Tanaman dan Cu-Turunan Klorofil Serta Karakteristik Fisiko-Kimianya. Jurnal Gizi dan Pangan. Vol. 4, No. $1 .$.

Nweze, N.O.,\& Nwafor,F. I. (2014). Phytochemical, proximate and mineral composition of leaf extracts of Moringa oleifera Lam. from Nsukka, SouthEastern Nigeria. IOSR Journal of Pharmacy and Biological Sciences, 9, 99-103

Purwono, B, dan Mahardani, C. 2009, Synthesis of Azo Compound Derivative From Eugenol and Its Application As A Titration Indicator, Indo. J.Chem., $10,95-98$

Richana N, Sunarti TC. 2004. Karakterisasi sifat fisikokimia tepung umbi dan tepung pati dari umbi ganyong, suweg, ubi kelapa dan gembili. Jurnal Pascapanen. 1(1): 29-37.

Ririn Tri Ratnasari, Mastuti H.Aksa .2011. Teori dan Kasus Manajeman Pemasaran Jasa. Edisi 1, Bogor : Ghalia Indonesia.

Rukmana, Rahmat.2008. Bayam, Bertanam dan Pengolahan Pascapanen. Yogyakarta: Kanisius.

Shiriki, D., Igyor, M.A. and Gernah, D.I. (2015). Nutritional evaluation of complementary food formulations from maize, soybean and peanut leaf powder. Food and Nutrition Sciences, 6, 494-500

Sofiatun, Diana. 2013.10 Manfaat Daun Pandan Wangi.

Sudarmadji, Slamet. 2003. Analisa Bahan Makanan dan Pertanian. Yogyakarta: UGM

Sunarni, T., Pramono, S., Asmah, R. 2007. Flavonoid Antioksidan Penangkap 
Radikal dari Daun Kepel (Stelechocarpus burahol (Bl.) Hook f. \& Th.), M.F.I., 18 (3) : 111-116.

Sunarjono, Hendro. 2013. Bertanam 36 Jenis Sayur. Jakarta: Penebar Swadaya.

Suprapti, L. 2005.Teknologi Pengolahan Pangan Tepung Tapioka dan Pemanfaatannya.PT Gramedia Pustaka: Jakarta. $80 \mathrm{hlm}$.

Syah D. 2009. Riset untuk Mendayagunakan Potensi Lokal: Pelajaran dari Industrialisasi Diversifikasi Pangan. Bogor: IPB Press

Tina, D. R., Yuli, S., dan Dede, S. 2015. Uji Aktivitas Antioksidan Biopigmen pada Fraksi Aseton dari Mikroalga (Chlorella vulgaris). Edisi Juni 2015 Vol. IX No. 1. ISSN 1979-8911.

Widjaya, C. H. 2003. Peran Antioksidan Terhadap Kesehatan Tubuh, Healthy Choice. Edisi IV. Winarno F.G. 2004. Kimia Pangan dan Gizi. PT Gramedia Pustaka Utama. Jakarta.

Winarno, F.G. 2002. Kimia Pangan dan Gizi.Jakarta: PT. Gramedia Pustaka Utama. Winarsih, S., 2007. Mengenal dan Membudidayakan Buah Naga. CV Aneka Ilmu, Semarang. 